\title{
有機 EL 素子における発光材料の研究
}

\author{
(1992 年 4 月 18 日受理)
}

\section{東 久 洋*・細川地潮・東海林 弘・楠本 正}

\begin{abstract}
有機エレクトロルミネセンス (EL) 素子の青色系統の発光材料としてジスチリルベンゼン誘導体を 合成し，その置換基をアルキル基，電子求引基，電子供与基と系統的に変化させることにより検討を行 った。EL の発光効率を向上させる条件として薄膜性が良好であることと発光材料は正孔輸送層との工 キサイプレックス (exciplex) 形成, 電荷移動状態などを避けることが重要であることが明らかとなっ た。検討した一連の置換基の中では電子供与性のカルバゾール系が良好であった。具体的には $1.51 \mathrm{~m} /$ $\mathrm{W}$ 以上の青緑色発光を得ることができた。また化合物の共役状態を制御することにより青色発光も得 ることが可能であった。これらのジスチリルベンゼン誘導体系は青色系発光材料として有望であること を見いだした。
\end{abstract}

\section{1 楮言}

近年,フラットディスプレイパネルの研究がますます盛んにな ってきているが，その中でる特にエレクトロルミネセンス(EL) ディスブレイは最近注目を集めている。EL 素子の大きな特辡と して，自己発光による視珰性の高さや，固体素子であるため耐衝 得に優れるといったことが挙げられる。無機 EL 素子の現状は, 印加電圧か $100 \mathrm{~V}$ 程度と高く, また㬰用化されているのは黄橙色 のみで青，赤は低輝度発光のみしか得られていない。特に青色発 光については素子作製の難しさから非常に困難なものとなってい る。一方有機 EL 素子の歴史を振り返ると, アントラセン単結晶 あるいはフントラセン薄膜を用い明所可視の発光を得た研究を出 発点としている(12)。その後低印加電王, 高輝度発光の先駆けとな ったのは 1987 年 Kodak 社の Tang らであり,トリフェニルア ミン系材料を正孔渝送層としその上にフルミキレートを発光層と

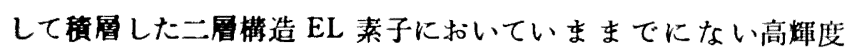
$\left(1000 \mathrm{~cd} / \mathrm{m}^{2}\right.$ 以上), 高効辛 $(1.5 \mathrm{~lm} / \mathrm{W})$ な緑色発光を得た ${ }^{3)}$ 。ま た，彼らはアルミキレートをホストとしたドーピンク有機 EL 素 子で青粶から撜赤色までの高辉度発光を実現しだ。一力, 安達 らは電子注入層を用いた三層構造(1) るいは正孔輸送発光層(1で 高端度の発光を得ている。

出光興産式会社中央研究所新材料研究所, 299-02 袖ヶ 浦市上鼠 1280

1) W. Helfrich, W.G.Schneider, Phys. Rev. Lett., 14, 229(1965).

2) P. S. Vincett, W. A. Barlow, R. A. Hann, G. G. Roberts, Thin Solid Films, 94, 171(1982).

3) C.W. Tang, S. A. Vanslyke, Appl. Phys. Lett., 51, 913(1987).

4) C.W. Tang, S. A. Vanslyke, C. H. Chen, J. Appl. Phys., 65, 3610(1989).

5) C. Adachi, S. Tokito, T. Tsutsui, S. Saito, Jpn. J. Appl. Phys., 27, L 713 (1988).
著者らも以前から独自に有機 EL の発光材料の研究を行ってき た。まず青色発光材料として蛍光增白剤やレーザー用色素として も有名なジスチリルベンゼン誘導体に焦点を絞り EL 発光材料と しての評価を行っだその結果ジスチリルベンゼン誘導体の単層 で $20 \sim 30 \mathrm{~cd} / \mathrm{m}^{2}$ の青色発光を得たが, Kodak 社の発表後)積層 型での高効率化を図っだ ${ }^{72)}$ この研究の段階で積層型 EL 素子 に扣ける発光材料の特性を研究すべくジスチリルベンゼン誘導体 の置換基効果を系統的に検討してきた。今回これまでの結果をま とめて報告する。

\section{2 実験}

\section{1 発光材料の合成}

今回発光材料として用いたジスチリルベンゼン誘導体について はすべて Wittig 反応より合成した ${ }^{18)}$ 。塩基としてはナトリウム エトキシドやカリウム坖トキシドなどのアルコキシドあるい はブチルリチウムを用いた。溶媒はェタノール, テトラヒドロフ ランあるいはジメルスルホキシドを用いた。生成物はすべてョ ウ妻処理することによりトランス体へ転換した。トランス化は赤

6) C. Adachi, T. Tsutsui, S. Saito, Appl. Phys. Lett., 55, 1489(1989).

7) 細川地潮, 東海林 弘, 東 久洋, 楠本 正, 電子情報通 信学会技術研究報告, EID-89-48, 41(1989)。

8) C. Hosokawa, H. Tokailin, H. Higashi, T. Kusumoto, Acta Polytec Scand., ph 170, 219(1990).

9) N. Nohara, M. Hasegawa, C. Hosokawa, H. Tokailin, T. Kusumoto, Chem. Lett., 1990, 189.

10）東 久洋, 細川地潮, 東海林弘, 楠本正, 日本化学会 第59春季年会予稿集, 3E 146(1990 神奈川).

11) 東 久洋, 細川地潮, 東海林弘, 楠本 正, 日本化学会 第62秋季年会予稿集，3G 109(1991 北海道).

13）楠本 正, 細川地潮, 東海林 弘, 束 久洋, 第40回高分 子討論会予稿集, 2 G 10(1991).

13) R. N. Mcdonald, T. W. Campbell, J. Org. Chem., 24, 1969(1959). 
(1) Multilayer type EL cell (A)

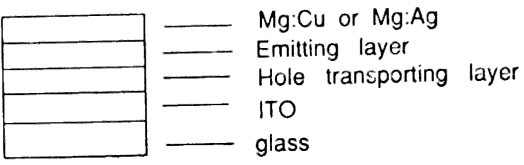

(2) Multilayer type EL cell (B)

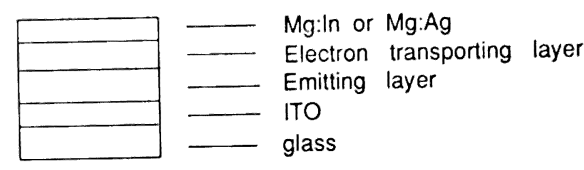

(3) Monolayer type EL cell

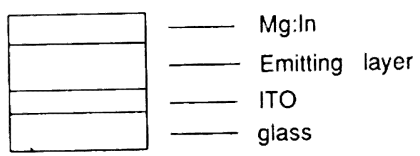

$$
\begin{aligned}
& \text { (ㅇ) } \mathrm{N}-(\mathrm{O})-\mathrm{O}-\mathrm{N}-\mathrm{O} \text { (O) } \\
& \text { TPO PBD }
\end{aligned}
$$

Fig. 1 Configuration of EL cells and molecular structures of diamine(TPD) and oxadiazole derivative(PBD)

外吸収スペクトルの $\delta(\mathrm{CH}) 980 \mathrm{~cm}^{-1}$ が増加することにより確認 した。

\section{2 素子作製及び構成}

Kodak 社の Tang らと同様の素子構成で EL 性能を評価した (図 1 ( 1 ) 積層 A 型)。ITO/TPD $(60 \mathrm{~nm}) /$ 発光層 $(60 \mathrm{~nm}) / \mathrm{Mg}$ : $\mathrm{Cu}$ or $\mathrm{Mg}: \mathrm{In}(130 \mathrm{~nm})$ 。これとは別に正孔輸送型発光層 (図 1 （2）積層 B 型）として評価する場合の素子構成は ITO/発光層/ $\mathrm{PBD} / \mathrm{Mg}:$ In or $\mathrm{Mg}: \mathrm{Ag}$ とした。また単層（図 1（3））で比 较する場合の素子構成は ITO/発光層 $(120 \mathrm{~nm}) / \mathrm{Mg}: \mathrm{In}$ である。 今回用いた素子構成と正孔輸送材料のジアミン化合物 (TPD) お よび電子注入材料のオキサジアゾール化合物 (PBD) の構造を図 1 に示した。有機物と金属電極は真空蒸着法で薄膜化した。基板 温度はすべて室温とした。また，正孔輸送層と発光層の膜厚はほ ほ $60 \mathrm{~nm}$ に固定した。な拈，素子の有效電極面積は $3 \mathrm{~mm} \times 5$ $\mathrm{mm}$ である。また，陰極は複数種の組み合わせを用いているが， 陰極は $\mathrm{Mg}$ を主体とし，これに微量の第二金属を 10:1 の比で 蒸着したものであり，初期においては陰極の違いによる差異はほ とんどないことを確認している。

\section{3 結果と考察}

\section{1 アルキル置換ジスチリルベンゼンの発光特性}

発光材料として用いるアルキル直換ジスチリルペンゼン誘導体 の電子的性質を検討した。用いた誘導体の榄造式および略号を図

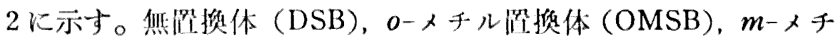
儿置換体 (MMSB), $p$ 一メチ儿置換体 (PMSB) また $p$-ェチル置 換体 (PESB), $p$-イソプロピル置換体 (IPSB), $p$-(t-プチル) 植 換体（TBSB）の溶液状態の吸収スペクトルと溶液状態の监光ス ペクトルを測定すると，吸収ピークは $340,360,375 \mathrm{~nm}$ に見られ
(2)

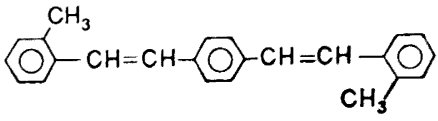

(3)<smiles>Cc1cccc(C=Cc2ccc(C=Cc3cccc(C)c3)cc2)c1</smiles>

MMSB

(4) $\mathrm{CH}_{3}-\mathrm{O}-\mathrm{CH}=\mathrm{CH}-\mathrm{O}-\mathrm{CH}=\mathrm{CH}-\mathrm{O}-\mathrm{CH}_{3}$

PMSB

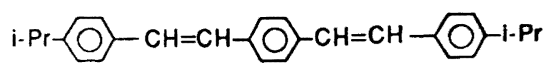

IPSB

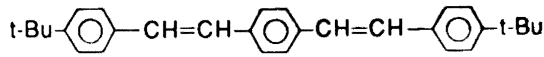

TBSB

Fig. 2 Molecular structures and the abbreviation of distyrylbenzene materials

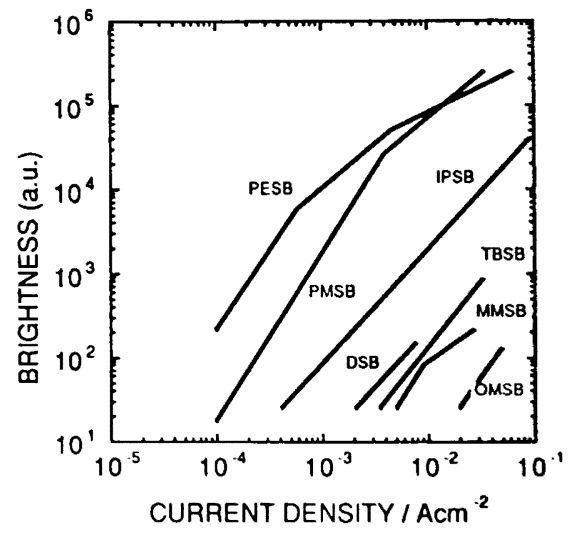

Fig. 3 Brightness-current density characteristics of seven EL cells

蛍光ピークは $400,420 \mathrm{~nm}$ に見られた。誘導体間で吸収ピークあ るいは蛍光の相対効率に祭立った差異は見られなかった。たた し, OMSB のスペクトルはブロードとなり、これは立体障害によ るフェニル環のねじれによるむのである。またこれらの化合物の 薄膜状態のイオン化エネルギーとエネルギーギャッブを测定した 結果，との直換基材料でもほとんど变化なく，それぞれ5.9.2.8 $\mathrm{eV}$ であった。(イオン化ェネルギーは理研計器赀の大気中桑外光 電子分光装置 $\mathrm{AC}-1$ を用い，粉末状態で測定した。また。エネル ギーギャッブについては溶液状抬の吸収スペクトルを湖定し、吸 収端のエネルギーより兄程もった)。これらの結果からこのアル キル潐換した発光性料の電子的性筫はほとんど同じであることが 判明した。

これらの化合物を発光材料として程底 A型り秦子構成で EL 効

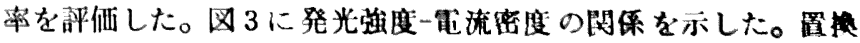

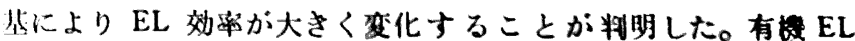


素子を愉討する場合まず薄膜性といらことが重要な要冈である。 因 3 中で, OMSB やDSB は発光効率が低いが, 発光層は目視で 白沟していることがわかった。実際にこれらの素子の SEM 写 真筄察を行らと, 発光村料が正孔輸送層の上に島状に結晶化して おり，結晶料間に陁間があるのが観察された。結晶粒径が大きく 薄膜性の悪いものは EL 効率が大きく低下寸ることが明らかとな った。

一方，EL 効率が良好であったのは PMSB， PESB であり特に PESB では $9 \mathrm{~V}$ の電圧印加時に $4.7 \mathrm{~mA} / \mathrm{cm}^{2}$ の電流が流れ, 輝 度 $44 \mathrm{~cd} / \mathrm{m}^{2}$ の青色発光が得られた（効率 $0.33 \mathrm{~lm} / \mathrm{W}$ )。電圧を 上昇させると $200 \mathrm{~cd} / \mathrm{m}^{2}$ 以上の輝度が得られた。PESB は断面 SEM 写真観察より, 非常に緻密で均一な薄膜が形成されている ことも判明した。しかし, 薄膜性に優れていても発光効率の悪い 化合物もあった。たとえば TBSB では $20 \mathrm{~V}$ の電圧印加時に 36 $\mathrm{mA} / \mathrm{cm}^{2}$ の電流が流れ輝度は $10 \mathrm{~cd} / \mathrm{m}^{2}$ であった。

3.2 アルキル置換ジスチリルベンゼンの発光スペクトル

アルキル值換ジチリルペンゼンの電子的性質は差異が見られ ないが，EL 発光特性に大きな違いが見られた点に注目し，EL ス ベクトルを詳細に比較した。因4 に PESB, 図 5 にTBSB の積 層 $\mathrm{A}$ 型での $\mathrm{EL}$ スペクトルを示す。TBSB のスペクトルは長波長 僋にブロードな尾を引いている。薄膜状態の蛍光スペクトルと比 校すると PESB はスペクトルがほぼ一致するが, TBSB では EL スペクトルが長波長化していることがわかった。比較のため に TBSB の単層型の素子を作製し，EL スペクトルを測ると蛍光 スベクトルとほぼ一致してお゙り, 積層型 EL 素子の場合のみ長波

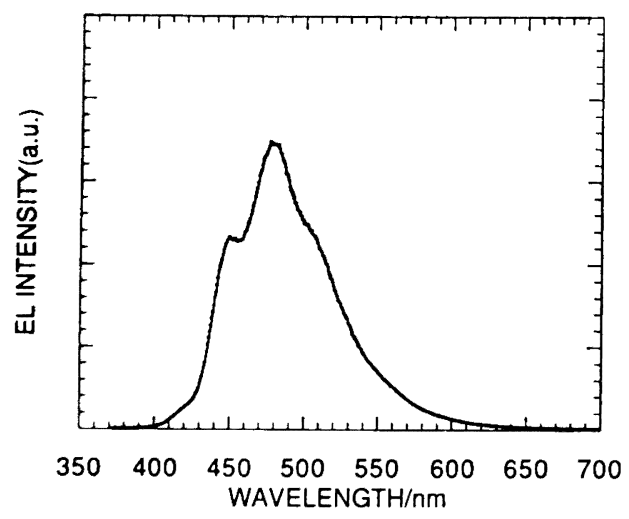

Fig. 4 EL spectrum of ITO/TPD/PESB/Mg: $\mathrm{Cu}$

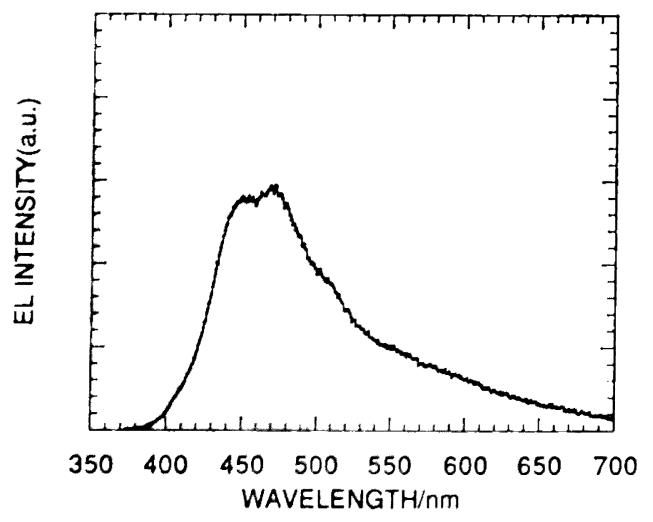

Fig. 5 EL spectrum of ITO/TPD/TBSB/Mg: Cu
長化していることが明らかとなった。このように TBSB 積層素 子で EL スペクトルが長波長化していることは, 正孔輸送層と発 光層での界面 (励起) 状態の影響, 具体的には異種分子間のエキ サイプレックス形成もしくは電荷移動状態 (ECT) と考えられる。 TBSB 以外のほかの EL 効率が低い系でも EL スペクトルの長 波長化は観察された。このことから, 界面励起状態が EL 効率低 下の要因であることを強く示唆している。

\section{3 電子供与, 求引性置換基をもつジスチリルベンセンの検討}

3.3.1 皘層 $\mathbf{A}$ 型での検討：上記の界面での相互作用状態と EL 効率との関係を明確にするために，次にジスチリルベンゼン に電子供与性基あるいは電子求引性基を導入することにより, EL 発光特性に及ぼす影響を検討した。電子供与性基として 3-カ ルバゾリル基, アミノ固換フェニル基を, 電子求引性基として 2-キノリル基を末端に導入したジスチリルベンゼン誘導体もアル キル置換体と同様に合成した。化合物の構造式と略号を図 6 に示 す。なおここであげた材料の薄膜性はすべて良好であった。積層 A 型での発光強度-電流密度の特性を図 7 に示す。参考のために 3.1 で検討したPESB のデータも同時に示している。供与性基で あるカルバゾリル基や(ジフェニルアミノ)フェニル基を導入した

$X-\mathrm{CH}=\mathrm{CH}-\mathrm{O}-\mathrm{CH}=\mathrm{CH}-\mathrm{Y}$
(1) $X=Y=$

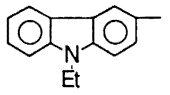
$\mathrm{BCzVB}$
(2) $X=Y=$<smiles>CCNc1ccc(C)cc1</smiles>
BEAVB
(3) $X=Y=$<smiles>Cc1ccc(N(c2ccccc2)c2ccccc2)cc1</smiles>
BPAVB

(4) $X=Y=$<smiles>Cc1ccc2ccccc2n1</smiles>

BQVB

(5) $X=\mathrm{Me} \widehat{O} \mathrm{O} \quad \mathrm{N}=\mathrm{O}-\mathrm{QPVB}$

Fig. 6 Molecular structures and the abbreviations of distyrylbenzene materials

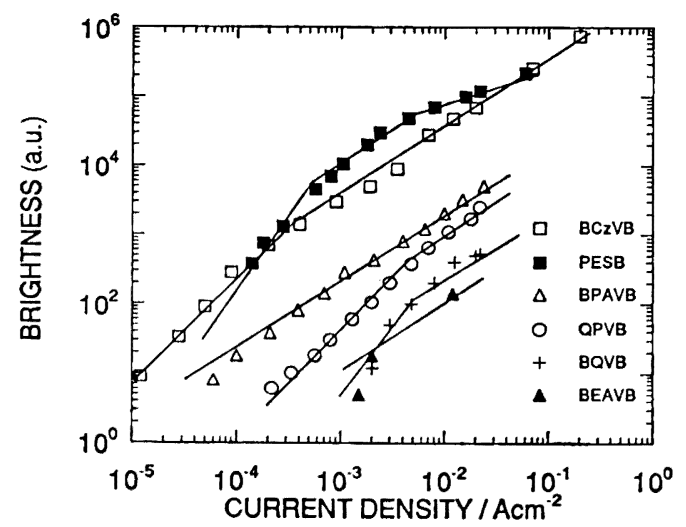

Fig. 7 Brightness-current density characterisics of EL cells 
ものが発光効率が良好であり，特にカルバゾリル基を有するジス チリルベンゼン $(\mathrm{BCzVB})$ は, 輝度 $40 \mathrm{~cd} / \mathrm{m}^{2}$, 効率 $0.3 \mathrm{~lm} / \mathrm{W}$, （EL 発光波長 $\lambda_{\max }=487 \mathrm{~nm}$, 青緑色発光）と, PESB と同程度 の良好な効率が得られ，10 V の電王で輝度は $1000 \mathrm{~cd} / \mathrm{m}^{2}$ を越え た。逆に, 電子求引性基であるキノリル基を有するものは低効率 であった。ここで EL スペクトルを詳細に測定したところ, 電子 供与性基では蛍光スペクトルと同じで，電子求引性基では大きく 長波長化していた。電子求引性基を有する化合物は電子供与性の 正孔輸送材料のジアミン化合物 (TPD) とエキサイプレックス形 成，電荷移動状態などを形成し発光効率の低下を招いたことを示 している。

3.3.2 栍層 $\mathrm{B}$ 型での検討：積層 $\mathrm{A}$ 型での検討で電子供与性基 であるカルバゾリル基を有する化合物が高効率であったが，カル バゾリル基は正孔輸送能も有すると考兄, 積層 $\mathrm{B}$ 型（正孔輸送型 発光層) で検討を行った。図 8 に発光強度-電流密度の関係を示 すが, 積層 $\mathrm{A}$ 型の素子構成よりもさらに発光効率に優れており， $7 \mathrm{~V}, 80 \mathrm{~mA} / \mathrm{cm}^{2}, 620 \mathrm{~cd} / \mathrm{m}^{2}$, 効率 $0.35 \mathrm{~lm} / \mathrm{W}$ と非常に良好であ ることがわかった。このときの EL スペクトルは単層型と一致し て拈り，発光層と電子注入層 (PBD) との間でスペクトル的には エキサイプレックス形成，電荷移動状態などは観測されなかっ

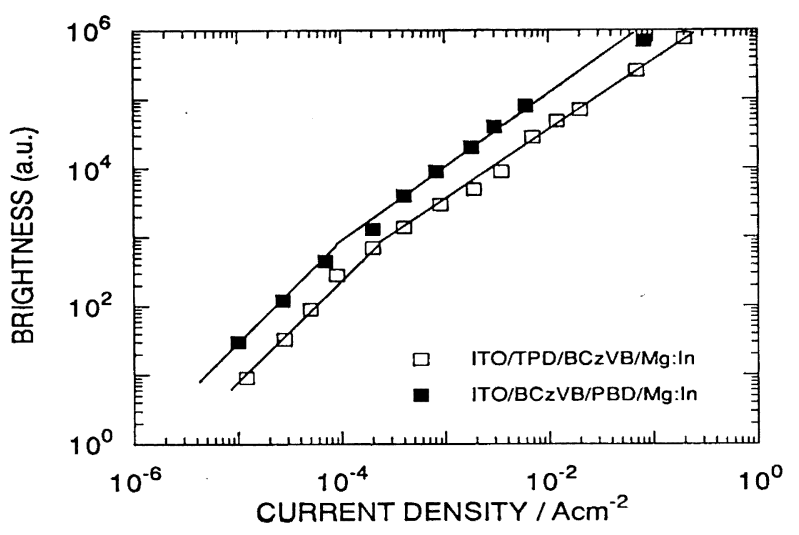

Fig. 8 Brightness-currentdensity characteristics of EL cells

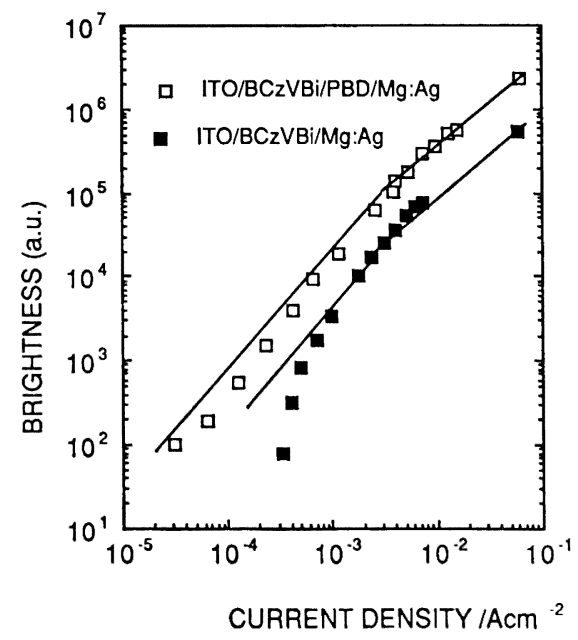

Fig. 9 Brightness-current density characteristics of EL cells
た。

ここでカルパソール系固換体をより詳しく研究するため, 中心 骨格をフェニレンからビフェニリレンにか党た化合物（BCzVBi 図 $10(2))$ で同様に積層 B 型で検討すると, BCzVB よりもさら に高効㸉な EL 発光が得られた。（図9）具体的にデータを示す と,

（1）積凮 $\mathrm{B}$ 型 ITO $/ \mathrm{BCzVBi} / \mathrm{PBD} / \mathrm{Mg}: \mathbf{A g}$

$7 \mathrm{~V}, 61 \mathrm{~mA} / \mathrm{cm}^{2}, 2000 \mathrm{~cd} / \mathrm{m}^{2}, 1.5 \mathrm{~lm} / \mathrm{W}$

青緑色発光 $\left(\lambda_{\max }=492 \mathrm{~nm}\right)$

(2) 単層 ITO $/ \mathrm{BCzVBi} / \mathrm{Mg}: \mathrm{Ag}$

$8 \mathrm{~V}, 28 \mathrm{~mA} / \mathrm{cm}^{2}, 600 \mathrm{~cd} / \mathrm{m}^{2}, 1.0 \mathrm{~lm} / \mathrm{W}$

青緑色発光 $\left(\lambda_{\max }=487 \mathrm{~nm}\right)$

また（1）と（2）のスペクトルは一致したことから，発光居と 電子注入增 (PBD) との間で, スペクトル的にはエキサイブレ, クス形成，電荷移動状態などでは観測されなかった。ここで注目 すべきことは BCZVB や BCZVBi などのカルパソール系化合物 が積層 $\mathrm{A}$ 型， $\mathrm{B}$ 型, 単層などのどの素子構成でも高効率である点 である。

つぎに同じく電子供与性で，積層 $\mathrm{A}$ 型で $\mathrm{BCzVB}$ に次いで协率 の良かった（ジフェニルアミノ）フェニル固換体の中心骨格ビフ エニリレン化合物を合成し（因 $10 （ 3 ）$ ) 検討した。積層 B 型で 検討すると,

(3) ITO/BPAVBi $/ \mathrm{PBD} / \mathrm{Mg}: \mathrm{Ag}$

$6 \mathrm{~V}, 56 \mathrm{~mA} / \mathrm{cm}^{2}, 1260 \mathrm{~cd} / \mathrm{m}^{2}, 1.2 \mathrm{~lm} / \mathrm{W}$

青緑色発光 $\left(\lambda_{\max }=478 \mathrm{~nm}\right)$

であり（1）の $\mathrm{BCzVBi}$ を積層 $\mathrm{B}$ 型として用いた場合とほぼ同等 な高効率のデータが得られた。しかし、BPAVBi は積層A型ある いは単層では効率が悪く積層 $\mathrm{B}$ 型に比べて 2 桁低かった。

3.3.3 正孔移動度の検討：因 10 に示すように $\mathrm{BCzVBi}$ と BPAVBi のイオン化ポテンシャル $\left(I_{\mathrm{p}}\right)$ にはほとんど変化はなく $5.5 \mathrm{eV}$ 程度である。(なお。, 今回の測定は理研計器製の大気中紫
(1)

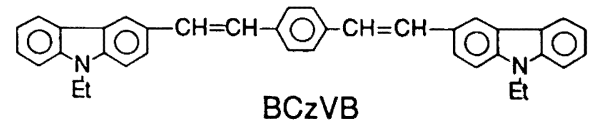

(2)

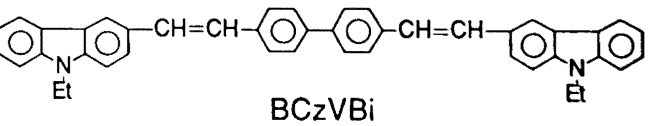
$\mathrm{BC} z \mathrm{VBi}$ $\mathrm{BCzVB}$ Et
$\mathrm{Ip}=5.5 \mathrm{eV}$ $\mathrm{Ip}=5.5 \mathrm{eV}$

(3)

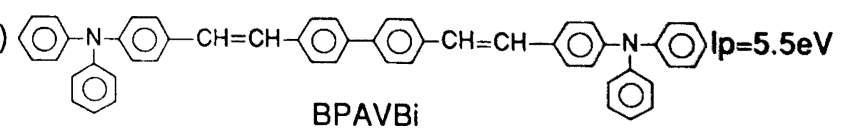

(4)

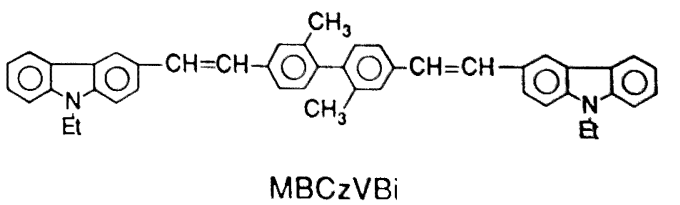
$\mathrm{Ip}=5.4 \mathrm{eV}$
Fig. 10 Molecular structures and the abbreviation of distyrylbenzene materials 


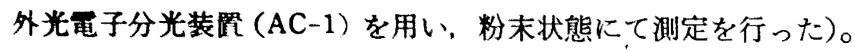
また，両者で，エネルギーギャップあかわらないことから，電子 親和力 $\left(A_{\ell}\right)$ あほぼ同じである。このように, 同じように電子供 与性の置基を有し， $I_{\mathrm{p}}, A_{\mathrm{f}}$ が同じ化合物であってもカルパゾ 一ル系は単㕣型、積層 $\mathrm{A}$ 型, $\mathrm{B}$ 型でも効率が良く, トリフェニル アミン系は積層 $\mathrm{B}$ 型 (正孔輸送型発光層) では高効㸉であるもの の単層，積層 $\mathrm{A}$ 型では 2 析も効率低下を起こす原因を調べるため に移動度を测定した。

なお，移動度の評価は著者らの開発したパルス EL 測定法 ${ }^{14)}$ により単層の EL 素子の発光達れ時間より算出した。その結果 $1 \mathrm{MV} / \mathrm{cm}$ 以上の電界で $\mathrm{BCzVB}$ の正孔移動度は $4 \times 10^{-4} \mathrm{~cm}^{2} / \mathrm{Vs}$ であり， $\mathrm{BCzVBi}$ は $8 \times 10^{-4} \mathrm{~cm}^{2} / \mathrm{Vs}$ であることがわかった。し かしこの方法では電子移動度は測定できなかった。また，BPAVBi は単層の発光が弱いために, 今回移動度の測定はできなかっ たが、一般にアミン系の移動度は $10^{-3} \mathrm{~cm}^{2} / \mathrm{Vs}$ 以上であることが 予想される(5)。したがって, カルハソール系はアミン系より正孔 移動度が約一桁悪いことが予想される。素子構成の違いによる発 光効率の差を論じるときには，正孔の移動度と電子の移動度との ハシランスが大きな一つの因子である。カルパ・ル系が積層 $\mathrm{A}$ 型, 積層 B 型, 単層のいずれの素子構成で発光効率が良好であっ たのは正孔移動度が大きくもなく，小さくもなく，それにともな い電子移動度のハランスるとれていたと考える。現在は正孔の移 動度のデータしかないが，電子の移動度も測定可能となれば，さ らに定量的評価ができるるのと考える。

\section{4 离愺度青色発光材料の検討}

いままで述べてきたよらに，著者らはカルパゾール系で非常に 高效率の青緑色発光を得ている。そこでこの効率は保ったまま高 媈度青色発光を得よらと分子設計した。具体的には中心構造を 2,2'-(ジメチルビフェリレン)として, ビフェニル部分のねじれ

14) C. Hosokawa, H. Tokailin, H. Higashi, T. Kusumoto, Appl. Phys. Lett., 60, 1220(1992).

15) M.Stolka, J.F. Yanus, D. M.Pai, J. Phys. Chem., 88, 4707(1984).
により共役状態を制御することとした（図 10（4）。実際に，積 層 $\mathrm{B}$ の素子構成で $\mathrm{MBC}_{2} \mathrm{VBi}$ の $\mathrm{EL}$ 測定を行うと, $12 \mathrm{~V}, 77$ $\mathrm{mA} / \mathrm{cm}^{2}, 200 \mathrm{~cd} / \mathrm{m}^{2}, 0.07 \mathrm{~lm} / \mathrm{W},\left(\lambda_{\max }=457 \mathrm{~nm}\right)$ の青色発光が 得られ，最高輝度は $1000 \mathrm{~cd} / \mathrm{m}^{2}$ 以上であった。しかし積層 $\mathrm{B} の$ $\mathrm{BC} z \mathrm{VBi}$ のデータ $(1.5 \mathrm{~lm} / \mathrm{W})$ に比べて効率は低い。このよ5に 共役状態を制御することにより求める青色発光を得ることができ たが，効率を上げることが今後の課題である。また，電子供与性 基導入による高輝度青色発光材料の実現として，DSB 末端への メトキシ基導入によりやはり $1000 \mathrm{~cd} / \mathrm{m}^{2}$ 以上の青色発光も得ら れた。

このよらに 1,4-ジスチリルベンゼソ，4,4'-ジスチリルビフェ ニル系は高効率の青色発光材料として非常に有用である。

\section{4 結 論}

アルキル置換あるいは電子求引性, 電子供与性基のジスッル ベンゼン誘導体を 15 種類合成し，各種素子構成で系統的に検討 し，以下の結果を得ることができた。

（1）高効率を得るには薄膜性が良好であること，界面でのエ キサイプレックス (exciplex) もしくは電荷移動状態などを避け ることが重要である。

（2）検討した化合物の中ではカルバゾール系が良好であっ た。特に $\mathrm{BCzVBi}$ は積層 $\mathrm{B}$ 型（正孔輸送型発光層）として用いる と効率 $1.5 \mathrm{~lm} / \mathrm{W}$ 以上と高効率であった。

（3）電子供与性のカルバゾリル基を有する化合物は積層 A 型 (Kodak 型), 積層 B 型 (正孔輸送型発光層), 単層いずれの場合 であ効率が良好であった。

（4）分子設計により青色で $1000 \mathrm{~cd} / \mathrm{m}^{2}$ 以上の高輝度も可能 である。

（5）以上の結果からジスチリルベンゼン, ジスチリルビフェ ニル系は高効率の青色発光材料として非常に有望である。

本研究の一部は日本化学会第 59 春季年会 (1990 年) 及び日本 化学会第 62 秋季年会（1991 年）にて発表済みである。 


\title{
Special Articles on \\ Organic and Inorganic Optical Materials
}

\author{
Studies on Emitting Materials of Organic EL Cells \\ Hisahiro Higashi*, Chishio Hosokawa, Hiroshi Tokailin \\ and Tadashi Kusumoto \\ Central Research Laboratories, Idemitsu Kosan Co. Ltd; \\ 1280 Kami-izumi, Sodegaura-shi 299-02 Japan
}

Fifteen distyrylbenzene (DSB) derivatives which were substituted by alkyl group, electronacceptor group or electron-donor group were synthesized and examined as an emitter for organic multilayer electroluminescence (EL) cells. We carefully measured the EL spectra and SEM pictures as well as the current-voltage and brightness-current characteristics. Then we conculded that it is very important for an emitting layer not to form exciplex or chargetransfer complex with hole transporting layer in addition to an ability to form a thin film. We found that 4, 4'-bis[2-(9-ethyl-3-carbazolyl)vinyl]biphenyl (BCzVBi) among those derivatives was very attractive material because we achieved the bright blue green light for the cell with $\mathrm{BCzVBi}$ as an emitting layer. We could obtain the luminance of $2000 \mathrm{~cd} / \mathrm{m}^{2}$ at a voltage of $7 \mathrm{~V}$ and the maximum EL efficiency of $1.5 \mathrm{~lm} / \mathrm{W}$ for the cell with $1 T O / \mathrm{BCz} \mathrm{VBi} / 2-$ (4-t-Butylphenyl)-5-(4-biphenylyl)-1,3,4-oxadiazole/Mg:Ag. We also achieved the bright blue light and the high luminance of more than $1000 \mathrm{~cd} / \mathrm{m}^{2}$ by introducing methyl group to biphenyl unit. Therefore the distyrylbenzene derivatives should be most promising compounds as EL emitting materials in the color range from blue to green. 